\title{
Long-term angiographic and clinical outcomes after coronary intervention using drug-coated balloons in acute coronary syndrome
}

\author{
(D) Klara Klarić*, \\ (1DZvonimir Ostojić, \\ (D) Kristina Marić Bešić, \\ DBoško Skorić, \\ (DIvan Škorak, \\ (D)Hrvoje Jurin, \\ (iD) Maja Strozzi, \\ (D)Eduard Margetić, \\ (iDoško Bulum
}

University of Zagreb School of Medicine, University Hospital Centre Zagreb, Zagreb, Croatia

RECEIVED:

February 18, 2020

ACCEPTED:

February 22, 2020

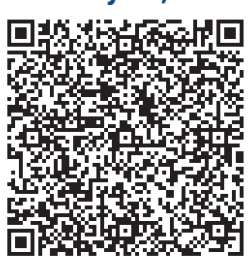

$\square$ Cardiologia Croatica 2020;15(3-4):52
KEYWORDS: acute coronary syndrome, percutaneous coronary intervention, in-stent restenosis, drug coated balloon

CITATION: Cardiol Croat. 2020;15(3-4):52-3. | https://doi.org/10.15836/ccar2020.52

*ADDRESS FOR CORRESPONDENCE: Klara Klarić, Klinički bolnički centar Zagreb, Kišpatićeva 12, HR-10000 Zagreb, Croatia. / Phone: +385-98-1923-241 / E-mail: klarus.klarum@gmail.com

ORCID: Klara Klarić, https://orcid.org/0000-0002-4180-692X •Zvonimir Ostojić, https://orcid.org/0000-0003-1762-9270 Kristina Marić, Bešić, https://orcid.org/0000-0002-4004-7271 • Boško Skorić, https://orcid.org/0000-0001-5979-2346 Ivan Škorak, https://orcid.org/0000-0002-4900-4876 • Hrvoje Jurin, https://orcid.org/0000-0002-2599-553X Maja Strozzi, https://orcid.org/0000-0003-4596-8261 • Eduard Margetić, https://orcid.org/0000-0001-9224-363X Joško Bulum, https://orcid.org/0000-0002-1482-6503

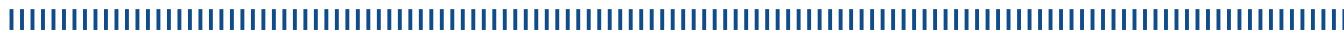

Aim: Aim of the study was to compare angiographic and clinical outcomes after percutaneous coronary interventions (PCI) using drug coated balloons (DCB) between patients treated for "de novo" lesions and in-stent restenosis (ISR) in acute coronary syndrome (ACS).

Patients and Methods: Study included 128 ASC patients treated with DCB between 2012 and 2019. All coronary angiographies were reviewed to determine indication, lesion complexity, vessel size and procedural success. Baseline and follow up clinical data were extracted from hospital digital database.

TABLE 1. Differences in clinical, angiographic and procedural characteristics between groups.

\begin{tabular}{|c|c|c|c|}
\hline & ISR (N=24) & Non-ISR (N=104) & $P$ value \\
\hline \multicolumn{4}{|l|}{ Clinical characteristics } \\
\hline Patient age & $68.36 \pm 6.85$ & $62.85 \pm 11.37$ & 0.002 \\
\hline Family history & $7(29.2)$ & $44(42.3)$ & 0.23 \\
\hline Active smokers & $3(12.5)$ & $40(38.5)$ & 0.015 \\
\hline Diabetes mellitus & $7(29.2)$ & $35(33.7)$ & 0.67 \\
\hline Arterial hypertension & $21(87.5)$ & $90(86.5)$ & 0.90 \\
\hline Hyperlipidaemia & $21(87.5)$ & $88(84.6)$ & 0.72 \\
\hline Previous myocardial infarction & $20(83.3)$ & $16(15.4)$ & $<0.001$ \\
\hline Atrial fibrillation & $3(12.5)$ & $6(5.8)$ & 0.24 \\
\hline Ejection fraction & $51.4 \pm 21.1$ & $54.3 \pm 18.2$ & 0.33 \\
\hline \multicolumn{4}{|c|}{ Angiographic and procedural characteristics } \\
\hline Vascular access - femoral & $6(25)$ & $36(34.6)$ & 0.36 \\
\hline Multivessel disease & $6(25)$ & $59(56.7)$ & 0.005 \\
\hline Bifurcation & $5(20.8)$ & $45(43.3)$ & 0.042 \\
\hline Number of used DCB & $1.0 \pm 0$ & $1.1 \pm 0.3$ & 0.004 \\
\hline Length $(\mathrm{mm})$ & $23.38 \pm 3.23$ & $21.24 \pm 5.24$ & 0.012 \\
\hline Diameter (mm) & $2.85 \pm 0.59$ & $2.48 \pm 0.49$ & 0.007 \\
\hline Bail out PCI & 0 & $8(7.7)$ & 0.16 \\
\hline Concomitant PCl & $8(33.3)$ & $79(75.9)$ & $<0.001$ \\
\hline Total number of stents per person & 0.5 & 1.2 & 0.002 \\
\hline
\end{tabular}

$9^{\text {th }}$ Croatian Conference on Interventional Cardiology - CROINTERVENT 2020 March 19-22, 2020|Zagreb, Croatia 
Results: Mean patient age was 63.8 years, with the majority being men (75.8\%, N=97). In total, 24 (18.8\%) patients were treated for ISR. Comparison of clinical, angiographic and procedural characteristics between groups is presented in Table 1. Patients in the non-ISR group had more often multivessel disease ( 56.7 vs $25.0 \%, p=0.005$ ), bifurcation PCI ( 45.0 vs $20.8 \%, p=0.042$ ) and more DCB used in the index event $(1.1 \pm 0.3$ vs $1.0 \pm 0, p=0.004)$. Furthermore, they had more concomitant PCI with stent implantation in other lesions (75.9 vs 33.3\%, p 0.001) with consequent higher number of stents implanted per person ( 1.2 vs $0.5, p=0.002)$. Both mean DCB diameter and length were larger in the ISR group $(2.85 \pm 0.59 \mathrm{~mm}$ vs $2.48 \pm 0.49 \mathrm{~mm}, \mathrm{p}=0.007$ and $23.38 \pm 3.23 \mathrm{vs} 21.24 \pm 5.24 \mathrm{~mm}$ $\mathrm{p}=0.012$, respectively). In the non-ISR group 8 (7.7\%) patients had "bail out" stent implantation, while none was done in ISR group. Mean angiographic and clinical follow up was not significantly different between groups (Table 2). Altogether 75 (58.6\%) patients underwent repeated coronary angiography, more often in the non-ISR group $(64.4 \%$ vs $33.3 \%, p=0.005)$ but most of those were elective (73.1\%). There was no significant difference in the composite endpoint consisted of death, unplanned rehospitalisation, target vessel revascularization and target lesion failure (ISR vs non-ISR; $29.2 \%$ vs 26.9\%, p=0.82), nor in any of its components (Table 2).

\section{TABLE 2. Comparison of clinical and angiographic outcomes between groups.}

\begin{tabular}{llll}
\hline & ISR (N=24) & Non-ISR (N=104) & P value \\
\hline Angiographic follow up (years) & $1.59 \pm 1.45$ & $0.87 \pm 1.38$ & 0.22 \\
\hline Clinical follow up (years) & $2.51 \pm 2.02$ & $2.52 \pm 2.36$ & 0.98 \\
\hline Repeated coronarography & $8(33.3)$ & $67(64.4)$ & 0.005 \\
\hline Elective & $6(25)$ & $85(55.8)$ & 0.006 \\
\hline Target lesion failure & $4(16.7)$ & $9(8.6)$ & 0.32 \\
\hline Target vessel revascularization & $2(8.3)$ & $7(6.7)$ & 0.78 \\
\hline Unplanned hospitalization & $6(25)$ & $18(17.3)$ & 0.38 \\
\hline Death & $1(4.2)$ & $5(4.8)$ & 0.89
\end{tabular}

Results are presented as mean \pm standard deviation or absolute number $(\%)$.

ISR=in-stent restenosis.

Conclusions: DCB in treatment of native coronary arteries provides similar angiographic and clinical outcomes compared to DCB for ISR in patients presenting with ACS in real-world settings. ${ }^{1}$ Furthermore, the prevalence of target lesion failure after DCB treatment was smaller in native coronary arteries compared to ISR.

1. Uskela S, Kärkkäinen JM, Eränen J, Siljander A, Mäntylä P, Mustonen J, et al. Percutaneous coronary intervention with drug-coated balloon-only strategy in stable coronary artery disease and in acute coronary syndromes: An all-comers registry study. Catheter Cardiovasc Interv. 2019 Apr 1;93(5):893-900. https://doi.org/10.1002/ccd.27950 